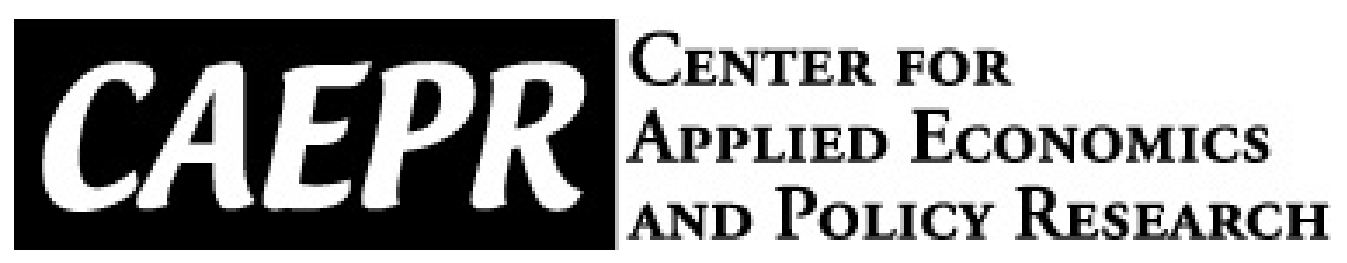

CAEPR Working Paper

\#2008-020

\title{
Skill Upgrading and the Real Exchange Rate
}

\author{
Roberto Alvarez \\ Central Bank of Chile
}

\author{
Ricardo Lopez \\ Indiana University Bloomington
}

July 14, 2008

This paper can be downloaded without charge from the Social Science Research Network electronic library at: http://ssrn.com/abstract=1159896.

The Center for Applied Economics and Policy Research resides in the Department of Economics at Indiana University Bloomington. CAEPR can be found on the Internet at:

http://www.indiana.edu/ caepr. CAEPR can be reached via email at caepr@indiana.edu or via phone at 812-855-4050.

(C2008 by Roberto Alvarez and Ricardo Lopez. All rights reserved. Short sections of text, not to exceed two paragraphs, may be quoted without explicit permission provided that full credit, including $($ ) notice, is given to the source. 


\title{
Skill Upgrading and the Real Exchange Rate*
}

\author{
Roberto Álvarez \\ Research Department, Central Bank of Chile \\ Intelis, University of Chile \\ ralvarez@bcentral.cl
}

\author{
Ricardo A. López ${ }^{* *}$ \\ Department of Economics \\ Indiana University \\ rialopez@indiana.edu
}

\begin{abstract}
This paper examines the effect of changes in the real exchange rate on skill upgrading in the case of Chile. Using plant-level data from the manufacturing sector we find that a real depreciation increases the share of skilled workers in the total wage bill in exporters but not in non-exporters. This result suggests that depreciations or, more generally, increases in export profitability, may induce exporters to adopt more skilled-intensive technologies. This finding gives support to recent models of trade that highlight the possible effect of the real exchange rate on skill upgrading and wage inequality. This paper also finds that real depreciations increase the probability of exporting and the export intensity of plants that export, suggesting that these two channels may explain why changes in the real exchange rate may affect wages.
\end{abstract}

Keywords: Skill Upgrading, Real Exchange Rate, Manufacturing

\footnotetext{
* We would like to thank Sarah Guillou, Stefanie Haller, Richard Kneller and participants at the International Activities and Firm Performance Workshop held at the University of Nottingham, Nottingham, UK, in February 2008 for many helpful comments and suggestions.

${ }^{* *}$ Corresponding Author. Address: Wylie Hall Room 105, Indiana University, Bloomington, IN 47405, U.S.A. Telephone: +1-812-856-1466. Fax:+1-812-855-3736. E-mail: rialopez@indiana.edu.
} 


\section{Introduction}

One of the salient characteristics of many developing countries, especially those from Latin America and Africa, is the high degree of income inequality between skilled and unskilled workers. Recent changes in trade orientation among these countries have provided interesting cases for studying how inequality responds to trade liberalization. Most of the empirical evidence in this area shows that trade liberalization is usually accompanied by increases in wage inequality (Goldberg and Pavcnik, 2004, 2007). ${ }^{1}$ This phenomenon is puzzling because developing countries are likely to be unskilled-labor abundant. According to the Stolper-Samuelson theorem, once these countries open to trade the returns to unskilled workers should increase in absolute terms as well as relative to the returns of skilled workers. Scholars have tried to explain this counterintuitive result from different angles. Some have argued that this pattern is consistent with the idea that developing countries are relatively abundant in natural resources rather than in unskilled labor (Leamer et al., 1999). Others have claimed that trade liberalization has been accompanied by skilled-biased technological change, which has increased the demand for skilled workers relative to unskilled workers (Robbins, 1996; Tokarick, 2005; Gallego, 2006). ${ }^{2}$

While most of the empirical studies focus on the inequality effects of trade liberalization, little work exists examining the effects of changes in export profitability on

\footnotetext{
${ }^{1}$ One exception is the case of Brazil, where wage inequality decreased during the trade liberalization (Gonzaga, Menezes-Filho and Terra, 2006). For other country-specific studies on this relationship see Beyer, Rojas and Vergara (1999), Hanson and Harrison (1999), Galiani and Sanguinetti (2003), Attanasio, Goldberg and Pavcnik (2004), and Acosta and Montes-Rojas (2008).

${ }^{2}$ The idea is that liberalizing developing countries may adopt skill-biased technologies developed in industrialized nations and this technology adoption may be motivated by tariff reductions in developing countries (as shown by Attanasio, Goldberg and Pavcnik (2004) in the case of Colombia). Zhu (2004, 2005) provides an alternative explanation based on product cycles. She argues that the reallocation of product-cycle goods from developed countries to developing countries increases the relative demand for skilled workers in developing countries, which raises wage inequality.
} 
wage inequality. ${ }^{3}$ In particular, no much attention has been given to exchange rate fluctuations and their impact on skill upgrading and wage inequality. ${ }^{4}$ The purpose of this study is to fill this gap. In this paper we complement previous evidence on trade and inequality by studying how changes in the real exchange rate (RER) affect wage inequality using plant-level data. We use information of Chilean manufacturing plants for the period 1990-1999 and compute 3-digit level industry-specific RERs. Thus, we extend Verhoogen (2008) paper that uses aggregate exchange rate fluctuations in Mexico. ${ }^{5} \mathrm{We}$ also try to identify the exact mechanism by which the RER and wages are related. ${ }^{6}$

This question is important for several reasons. First, episodes of significant trade reforms are becoming less common as many countries already liberalized their economies. But as countries trade more with one another they are exposed to other aspects of globalization such as changes in exchange rates. Thus, an understanding of the impact of globalization requires an examination of the effects of exchange rate movements on skill upgrading. Second, changes in the exchange rate may have similar effects as changes in tariffs on the price of imports, as shown by Feenstra (1989). ${ }^{7}$ Third, recent models of international trade with heterogeneous firms suggest that a real depreciation may induce skill upgrading, and contribute to increase wage inequality, by

\footnotetext{
${ }^{3}$ Changes in export profitability may be due to reductions in (fixed and variable) trade costs of exporting, such as free trade agreements or decreases in transport costs.

${ }^{4}$ One of the few papers examining the role of changes in the real exchange rate on income inequality is Guillaumont Jeanneney and Hua (2001), which shows that a real depreciation increased income inequality between urban and rural areas in China.

${ }^{5}$ Robertson (2003) also explores the relationship between aggregate exchange rate and relative wages in Mexico.

${ }^{6}$ Some scholars have used industry-specific exchange rates to examine the effect of exchange rate movements on labor-market outcomes (e.g., Goldberg, Tracy and Aaronson, 1999), but they have not given much attention to the impact on skill upgrading.

${ }^{7}$ This idea is called the "symmetry hypothesis."
} 
inducing firms to adopt new technologies and upgrade the quality of their products (Yeaple, 2005; Verhoogen, 2008; López, 2008).

This paper shows that firms facing a RER depreciation experience an increase in the share of skilled labor in the total wage bill, which is consistent with models in which an increase in export profitability induce the adoption of more skilled-intensive technologies. Our findings indicate that RER-induced skill-biased technological change within firms may explain an important part of increases in wage inequality in developing countries. The paper also shows that the effect of the RER on skill upgrading occurs through the effect on exporters. Thus, we are able to identify the channels by which the RER affects skill upgrading. In particular, we show that exchange rate fluctuations have significant effects on the probability of exporting and also on the share of foreign sales in exporting firms. Both dimensions of the data -the intensive and the extensive margin- are important to evaluate how real depreciations increase exports and accelerate the adoption of new technologies and product quality upgrading.

The results of this paper also have implications for policy. The growing participation of developing countries in the world trade challenges the view that they could be able reduce their levels of income inequality, unless they implement specific policies to compensate the earnings of those less favored with export opportunities. This paper shows that exchange rate fluctuations may also constitute a variable that policy makers should take into account. An important issue -though not addressed directly in this paper-is where displaced unskilled labor is reallocated. In some cases the transition may not be dramatic whenever reallocation is rapid and not costly. Some countries, however, have more rigid labor markets and natural or policy induced barriers to 
migration, and they may not be able to smooth this transition. In this case a rise in unemployment may occur.

This paper is structured as follows. In the next section, we describe the data and the main patterns. The third section presents the methodology. In the fourth section we show and discuss our results. Finally, the conclusions are presented in the fifth section.

\section{Data and Basic Patterns}

The plant-level data was obtained from the Annual National Industrial Survey (ENIA) carried out by the National Institute of Statistics of Chile. The ENIA contains information on sales, output, employment, wages, exports, foreign ownership, and other plant characteristics for each manufacturing plant with at least 10 employees. Each plant has a unique identification number which allows following them over time. In addition, plants are classified according to the International Standard Industrial Classification (ISIC) rev 2. This paper uses information for the years 1990 throughout 1999. All monetary variables were converted to constant pesos of 1985 using 4-digit ISIC level price deflators. Data on capital stock was not available so it was necessary to construct this variable using the perpetual inventory method for each plant. ${ }^{8}$

Although the ENIA distinguishes between non-production and production workers it does not have information about the educational level or the years of experience of each worker employed in each plant. In this paper we use non-production workers as a proxy for skilled labor. For unskilled labor we use information of production

\footnotetext{
${ }^{8}$ For the majority of plants, an initial value of the capital stock was available. This initial value was used to construct the capital stock data by adding investment and subtracting depreciation for each type of capital (machinery and equipment; buildings; and vehicles). For a small group of plants it was not possible to construct the stock of capital, so they were dropped from the data set.
} 
workers. As shown by Slaughter (2000), the results of using measures of production and non-production workers are comparable to those using levels of education as measures of skill, which gives us confidence that our results can be interpreted in the context of skill upgrading and wage inequality between skilled and unskilled workers.

Figure 1 shows the evolution of the share of skilled labor in the total wage bill for the manufacturing sector of Chile during the years 1990-1999. The graph shows an increase in the share from $51 \%$ in 1990 to $57 \%$ in 1999 . The share was stable around $50 \%$ between 1990 and 1995 but it started to increase steadily from 1996.

As seen in Figure 2 the importance of skilled labor in total wages differs across sectors. Sectors such as chemicals and machinery and equipment have average shares for 1990-1999 above 50\% and in some case above 60\% (e.g., other chemical products). Sectors with low shares include footwear, wood products, furniture, and ceramics. The rate of change in the share of skilled labor also differs across sectors. Figure 3 shows that most sectors experienced an increase in the share of skilled labor between 1990 and 1999, with the highest increase occurring in professional equipment, apparel, non-ferrous metals, and printing. Sectors such as electrical machinery, food miscellaneous, plastics, and furniture experienced small decreases in the share of skilled labor.

The increase in the share of skilled labor in total wages suggests that plants may have experienced skill upgrading during the period. It is possible that external factors may have contributed to this either directly or indirectly. Factors such as foreign technology acquisition and links with multinational corporations constitute direct sources of technology and may induce skill upgrading of local plants. In the case of Chile these sources are present in a relatively low fraction of plants. As seen in Table 1, during the 
period 1990-1999 an average of 5.6\% of plants purchased foreign technologies through licensing, while only $6 \%$ of plants had some foreign ownership.

But indirect sources of foreign technology may also be important determinants of skill upgrading in Chilean manufacturing. Contacts with foreign customers through exporting, and with suppliers through importing intermediate inputs, may allow plants to acquire information about foreign technologies, which may induce skill upgrading. A significant fraction of Chilean manufacturing plants participate in international markets either through exporting or importing intermediate inputs. As seen in Table 1, more than $22 \%$ of the plants exported part of their output during 1990-1999, while more than $25 \%$ imported intermediate inputs during the same period. The fraction of plants in both categories increased during the period, suggesting that foreign influences through exporting and importing may have become increasingly important.

\section{Methodology}

We follow the methodology used by Pavcnik (2003) where the share of skilled labor in total wage bill is derived from a translog cost function. This approach assumes that capital is a quasi-fixed factor of production and that plants minimize the cost of skilled and unskilled labor. This cost minimization yields the following expression:

$$
\text { Share }=\beta_{0}+\beta_{1} \ln \left(w^{s} / w^{u}\right)+\beta_{2} \ln (K / Y)+\beta_{3} \ln (Y)+\beta_{4} \text { Tech }+\varepsilon,
$$

where Share is the share of skilled labor in the total wage bill, $w^{s}$ is the skilled labor wage, $w^{u}$ is the unskilled labor wage, $Y$ is value added, $K$ is capital, Tech represents the observed component of technology, and $\varepsilon$ is the unobserved technological component. 
We expand this equation in two main ways. First, we proxy the unobserved technological component not only by the value of foreign technology licenses as in Pavcnik (2003), but also by the value of imported intermediate inputs, and foreign ownership. Second, we explore how industry-specific changes in export profitability may affect skill upgrading. To do that, we compute 3-digit ISIC sector-level real exchange rates. The natural log of the real exchange rate for industry $j$ at time $t$ is calculated as:

$$
\ln \left(R E R_{j t}\right)=\ln \left(\sum_{c=1}^{C} \alpha_{c j} R E R_{c t}\right),
$$

where $R E R_{c t}$ is the bilateral real exchange rate between Chile and country $c ;{ }^{9} C=15$ is the number of countries; and $\alpha_{c j}$ is defined as:

$$
\alpha_{c j}=\frac{1}{T} \sum_{t=1}^{T} \frac{\text { Exports }_{c j t}}{\operatorname{Exports}_{j t}}
$$

where Exports $_{c j t}$ is the value of exports from industry $j$ to country $c$ at time $t$; Exports $j$ is the value of exports from industry $j$ at time $t$; and $T$ is the number of periods (9 years). ${ }^{10}$ In other words, the real exchange rate is a weighted average of bilateral real exchange rate indices between Chile and the 15 main countries of destination of Chilean exports for each industry. These countries represent between $81.2 \%$ and $99.5 \%$ of total exports in each sector. The average coverage across all sectors is $92 \%$. An increase in this variable represents a real depreciation of the Chilean currency.

\footnotetext{
${ }^{9}$ The bilateral real exchange rate between Chile and country $c$ is: $R E R_{c t}=N o m E R_{c t} * P_{c t} / P_{C h i l e, t}$. NomER $R_{c t}$ is the nominal exchange rate between Chile and country $c$ (Chilean pesos / country's $c$ currency), while $P_{c t}$ and $P_{\text {Chile, }}$ are producer price level indices for country $c$ and Chile, respectively. The nominal exchange rates and producer prices were obtained from the International Financial Statistics of the International Monetary Fund. In cases in which the producer price was not available the consumer price index was used. ${ }^{10}$ We use the average over time to isolate the effect of changes in relative prices rather than changes in export shares.
} 
Figure 4 show variation in industries profitability associated with changes in real exchange rate. Most of the manufacturing industries experienced a real depreciation between 1990 and 1999. The most important increases correspond to printing and transport equipment. By contrast, some other industries, such as food and paper, saw reductions in their real exchange rates. In the empirical section, we will explore whether these across industries differences can explain variations in skill upgrading.

Using plant-level data, we estimate the following equation:

$$
\begin{aligned}
\text { Share }_{i j t} & =\delta_{i}+\delta_{1} \ln \left(K_{i j t-1} / Y_{i j t}\right)+\delta_{2} \ln \left(Y_{i j t}\right)+\delta_{3} \text { Lic }_{i j t}+\delta_{4} I m p_{i j t}+\delta_{5} \text { For }_{i j t} \\
& +\delta_{6} \ln \left(R E R_{j t}\right)+\gamma \text { Year }_{t}+\varepsilon_{i j t},
\end{aligned}
$$

where $i$ denotes a plant, $j$ a 3-digit ISIC industry, Year is a vector of year-specific effects, and $\delta_{i}$ are plant-specific fixed effects. Lic, Imp and For, are measures of foreign technology licensing, imports of intermediate inputs, and foreign ownership, respectively (see next section for the exact way in which we measure them). Since the current capital stock may be affected by relative wages, the regressions use the lagged value of capital stock instead of the current value. Table 2 presents descriptive statistics for most of the variables.

Note that equation (2) differs from equation (1) also because it excludes relative wages. Pavcnik (2003) argues in favor of this practice because most of the variation in relative wages across plants is endogenous. We also try to avoid this problem by excluding this variable. As a robustness check, we estimate (2) including the relative wage between skilled and unskilled workers. The estimates for all other variables remain unchanged. ${ }^{11}$

\footnotetext{
${ }^{11} \mathrm{We}$ also estimate the equation by using the median of relative wages in the region where the plant is located instead of plant-specific relative wages. The results do not change.
} 


\section{Results}

\subsection{Skill Upgrading and the RER}

The basic results for the effect of the RER on the share of skilled labor are presented in Table 3. We show estimates using the sample of all plants, as well as for non-exporters and exporters separately. If changes in RER induce exporters to upgrade the quality of their products, then it is likely that the RER affects the share of skilled labor mostly on exporters. We use two alternative ways to measure the influence of foreign technology licenses and imports of intermediate inputs. The first simply uses a dummy variable equal to one for plants that report the use of foreign technology licenses and imported inputs. The results of the estimations using these variables are shown in columns (1)-(3). The second alternative takes into account the intensity of foreign licenses and importing inputs in each plant. This is done by using the value of royalties and license fees divided by sales as a measure of the intensity foreign technology acquisition, and by using the ratio of imported intermediate inputs over total intermediate inputs purchased by the plant to measure the degree of reliance on foreign inputs in each plant.

As seen in the table, the estimates for the ratio capital-value added are never statistically significant; suggesting that at least during this period capital is not complementary to skilled labor. In other words, within a plant and holding everything else constant, an increase in the amount of capital a plant employs does not increase the share of skilled labor in total wages. The estimates for value added are negative but not significant for the case of exporters.

In terms of the technology variables, we can see in column (1), which uses data on all plants, that the use of foreign technology licenses and imported intermediate inputs 
increases the share of skilled labor in total wages. The dummy for foreign ownership is positive but not significant. These results suggest that foreign technology licenses and importing inputs make plants more skilled intensive. When distinguishing between nonexporters (column 2) and exporters (column 3) we see that the dummy for foreign ownership is negative in the case of non-exporters but positive for exporters, implying that links with multinational corporations increase skill intensity only if the plant participates in export markets. The estimates for the foreign technology licenses dummy and the importer dummy are not significant for non-exporters, while only the dummy for foreign licenses is significant in the case of exporters. When we use the intensity of licensing as well as the intensity of importing inputs we get a similar picture. Both technology variables are correlated with skill upgrading, while foreign licenses appear to be more important for exporting plants. Now, however, import intensity is significant for the case of non-exporting plants.

These results contrast what Pavcnik (2003) finds for the case of Chile for a different period. Using the same type of data she finds no significant effect of several technology variables, including imported inputs, on skilled wages when using plant fixed effects. One possible explanation for this difference is that Pavcnik (2003) employs data for 1979-1986. Most of the trade reform was completed by the end of the 1970s and during that period the economy started to specialize in natural-resource intensive activities closely linked to the comparative advantages of the country. Thus, although foreign technologies may be important determinants of skill upgrading they may not have been so important during this previous period. 
Our main variable of interest is the RER. As seen in columns (1) and (4) the estimate for this variable is positive and statistically significant when all plants are included in the regressions. But a closer look reveals that this significant effect is explained by the positive and significant impact of the RER on skilled wages in exporting plants. Given that increases in the RER reflect real depreciations of the Chilean currency, we can say that a real depreciation increases skill intensity, as measured by the share of skilled wages. This result is consistent with Verhoogen (2008) model and implies that increases in RER may induce exporting plants to upgrade product quality and become more skilled intensive. Since the RER is included in logs, its estimate suggests that a $1 \%$ increase in the RER increases the share of skilled workers in total wages in exporters by 0.07 percentage points. This significant increase implies that changes in the RER are likely to have important effects on skill upgrading and wage inequality.

As a robustness check we also include the change in the RER as an explanatory variable. It is possible that changes in the RER are also important in explaining skill upgrading. The results are presented in Table 4. The estimates for all the technology variables do not change significantly when the change in the RER is included. The estimate for the RER remains positive and significant for the sample of exporters but not significant for non-exporters. Finally, the estimates for the change in the RER are always negative but never significant, confirming the robustness of our basic set of results. We also estimate regressions with the change in the RER but excluding the level of the RER. The results, not reported here, show that the estimate for the change in the RER is never statistically significant, while the estimates for the other control variables do not change. 
As a final robustness check we estimate the basic regressions excluding the two sectors in which the RER increased over $100 \%$ between 1990 and $1999 .{ }^{12}$ It is possible that our results are driven by the influence of these two outliers. The results, not presented here, show that the estimate for the RER continues to be positive and statistically significant for exporters while it is not significant for non-exporters, confirming that our basic results are robust to the exclusion of these two sectors.

\subsection{Examination of Channels: RER and Exporting Activity}

Our basic results show that real depreciations increase the share of skilled workers but do not show the exact mechanism by which the RER may affect skill intensity. In Verhoogen (2008) and in López (2008) the channel by which a real depreciation may affect product quality, and skill upgrading, is by increasing the probability of exporting and/or increasing the export intensity of existing exporters. This is the channel we examine in this section.

We first estimate an equation for the probability of exporting as:

$$
\operatorname{Pr}\left(X_{i j t}=1\right)=\alpha_{i}+\beta \ln \left(R E R_{j t}\right)+\lambda \Omega_{i j t-1}+\varepsilon_{i j t},
$$

where $X_{i j t}=1$ if plant $i$ operating in sector $j$ exported at time $t, R E R_{j t}$ is the real exchange rate for industry $j, \Omega_{i j t-1}$ is a vector of plant characteristics lagged one period to minimize simultaneity problems, and $\alpha_{i}$ are plant fixed effects that attempt to control for unobserved characteristics that may affect the probability of exporting. If real depreciations increase the probability of exporting, then the estimate for $\beta$ should be

\footnotetext{
${ }^{12}$ These sectors are printing and transport equipment. The reason why these sectors experienced such a big increase in their RER is that the destination countries of their products during this period consisted mostly of Latin American countries that experienced episodes of extremely high inflation, such as Brazil, Peru and Argentina.
} 
positive and significant. The results of estimating this equation are presented in Table 5, column (1). Consistent with previous studies, we observe that larger plants, foreignowned plants, importers of intermediate inputs and those using foreign technology licenses are more likely to export. The estimate for the $\log$ of the RER, $\beta$, is positive and statistically significant at $1 \%$, indicating that higher levels of the RER are associated with a higher probability of exporting at the plant level. ${ }^{13}$

Several empirical studies (Roberts and Tybout, 1997; Bernard and Jensen, 2004) show that exporting is a highly persistence activity. This may be due to the existence of sunk costs of exporting, which may induce exporters to avoid exiting export markets in order to avoid paying those costs in case they decide to start exporting again. In order to investigate if exporting persistence may be affecting our results, we also include a lag of the export status in our regression. The results are presented in column (3). We can see that most variables now have estimates that are lower in magnitude compared to those in column (1), but size, foreign ownership, foreign licenses, and the dummy for importers of intermediate inputs are still positive and significant. The estimate for the lag of the export status is positive and significant, which is consistent with previous studies. Finally, the estimate for the RER remains positive and significant, confirming that real depreciations increase the probability of exporting even after controlling for the existence of sunk costs of exporting.

Finally, we examine if the RER affects export intensity of plants that export. We estimate the following equation:

$$
\frac{V X_{i j t}}{\text { Sales }_{i j t}}=\alpha_{i}+\beta \ln \left(R E R_{j t}\right)+\lambda \Omega_{i j t-1}+\varepsilon_{i j t},
$$

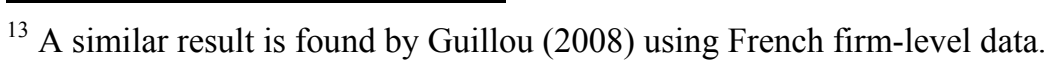


where $V X_{i j t}$ is the value of exports by plant $i$ at time $t$, and Sales $s_{i j t}$ is the value of total sales (exports plus domestic) of the same plant and year. The results are presented in Table 5, column (2). We can see that more productive and larger exporting plants export a higher fraction of their output. None of the other control variables is significant. The RER is positive and statistically significant, implying that a real depreciation increases export intensity in plants that export. ${ }^{14}$ Column (4) includes a lag of the ratio exports/sales. The estimate for this variable is positive and significant, but its inclusion does not affect the magnitude and the significance of the RER.

In summary, these results provide strong evidence that real depreciations increase the probability of exporting and export intensity, which appear to induce plants to upgrade the quality of their products and the skill intensity of their production techniques.

\section{Conclusions}

Recent models of international trade show that changes in export profitability affect firm decisions on the use of technologies and quality upgrading. This may change plants composition of employment toward more skilled labor, thus increasing income inequality. Complementing the previous literature this paper examines changes in industry-specific real exchange rates rather than trade liberalization episodes.

In general, the results are consistent with the idea that a real depreciation may be accompanied by an increase in the share of skilled labor in total wages. We also try to look at some of the mechanisms behind these results. We find that depreciations increase the probability of exporting and the export share of current exporters. The higher wage

\footnotetext{
${ }^{14}$ This result is consistent with Greenaway, Kneller and Zhang (2007), which shows that a one percentage point appreciation of the industry-specific RER in the UK reduces firms' export share by $1.28 \%$.
} 
inequality attributable to changes in export profitability generates important questions for policy makers in developing countries. First, it gives some evidence to evaluate the distributional effect of real exchange rate fluctuations. This is very relevant for some countries that have liberalized their trade and do not face significant trade restrictions in export markets, but they still face inequality pressures coming from variations in the real exchange rate. Second, the growing participation of these countries in the world trade challenges the view that they could reduce their levels of income inequality, unless they implement specific policies to compensate the earnings of those less favored with export opportunities. A third issue -though not addressed directly in this paper- is where displaced unskilled labor is reallocated. In some cases the transition may not be dramatic whenever reallocation is rapid and not costly. Some countries, however, have more rigid labor markets and natural or policy induced barriers to migration, and they may not be able to smooth this transition. In this case a rise in unemployment may occur. 


\section{References}

Acosta, P., and G.V. Montes-Rojas (2008) “Trade Reform and Inequality: The Case of Mexico and Argentina in the 1990s," World Economy 31(6): 763-780.

Attanasio, O., Goldberg, P.K., and N. Pavcnik (2004) “Trade Reforms and Wage Inequality in Colombia," Journal of Development Economics 74(2): 331-366.

Bernard, A. B., and J. B. Jensen (2004) "Why Some Firms Export," Review of Economics and Statistics 86(2): 561-569.

Beyer H., Rojas P., and R. Vergara (1999) "Trade Liberalization and Wage Inequality," Journal of Development Economics 59(1): 103-123.

Feenstra, R.C. (1989) “Symmetric Pass-Through of Tariffs and Exchange Rates under Imperfect Competition: An Empirical Test," Journal of International Economics 27(1-2): 25-45.

Galiani, S., and P. Sanguinetti (2003) “The Impact of Trade Liberalization on Wage Inequality: Evidence from Argentina," Journal of Development Economics 72(2): 497-513.

Gallego, F. (2006) "Skill Premium in Chile: Studying the Skill Bias Technical Change Hypothesis in the South," Central Bank of Chile Working Paper No. 363.

Goldberg, P.K., and N. Pavcnik (2004) “Trade, Inequality, and Poverty: What do we know? Evidence from Recent Trade Liberalization Episodes in Developing Countries," Brookings Trade Forum, 223-269.

Goldberg, P.K., and N. Pavcnik (2007) "Distributional Effects of Globalization in Developing Countries," Journal of Economic Literature 45(1): 39-82. 
Goldberg, L., Tracy, J., and S. Aaronson (1999) "Exchange Rates and Employment Instability: Evidence from Matched CPS Data," American Economic Review Papers and Proceedings 89(2): 204-210.

Gonzaga, G., Menezes-Filho, N., and C. Terra (2006) “Trade Liberalization and the Evolution of Skill Earnings in Brazil," Journal of International Economics 68(2): 345-367.

Greenaway, D., Kneller, R., and X. Zhang (2007) "Exchange Rates and Exports: Evidence from Manufacturing Firms in the UK," GEP Research Paper 2007/13, University of Nottingham.

Guillaumont Jeanneney, S., and P. Hua (2001) "How does the Real Exchange Rate Influence Income Inequality between Urban and Rural Areas in China?" Journal of Development Economics 64(2): 529-545.

Guillou, S. (2008) "Exports and Exchange Rate: A Firm-Level Investigation," OFCE Working Paper No. 2008-02.

Hanson, G., and A. Harrison (1999) “Trade Liberalization and Wage Inequality in Mexico," Industrial and Labor Relations Review 52(2): 271-288.

Leamer, E. E., Maul, H., Rodriguez, S., and P. Schott (1999) "Does Natural Resource Abundance Increase Latin American Income Inequality?" Journal of Development Economics, 59(1): 3-42.

López, R.A. (2008) "Do Firms Increase Productivity in Order to Become Exporters?" Oxford Bulletin of Economics and Statistics (forthcoming).

Pavcnik, N. (2003) "What Explains Skill Upgrading in Less Developed Countries?" Journal of Development Economics 71(2): 311-328. 
Roberts, M., and J. Tybout (1997) "The Decision to Export in Colombia: An Empirical Model of Entry with Sunk Costs," American Economic Review 87(4): 545-64.

Robertson, R. (2003) "Exchange Rates and Relative Wages: Evidence from Mexico," North American Journal of Economics and Finance 14(1): 25-48.

Robbins, D (1996) "HOS Hits Facts: Facts Win; Evidence on Trade and Wages in the Developing World", Development Discussion Paper No. 484, Harvard Institute for International Development.

Slaughter, M. J. (2000) "What are the Results of Product Price Studies and what can we Learn from their Differences?' in R. C. Feenstra (ed.), The Impact of International Trade on Wages, NBER Conference Volume. University of Chicago Press, Chicago.

Tokarick, S. (2005) "Quantifying the Impact of Trade on Wages: The Role of Nontraded Goods," Review of International Economics 13(5): 841-860.

Verhoogen, Eric (2008) "Trade, Quality Upgrading and Wage Inequality in the Mexican Manufacturing Sector," Quarterly Journal of Economics 123(2): 489530.

Yeaple, S. (2005) "A Simple Model of Firm Heterogeneity, International Trade, and Wages," Journal of International Economics 65(1): 1-20.

Zhu, S.C. (2004) "Trade, Product Cycles and Inequality Within and Between Countries," Canadian Journal of Economics 37(4): 1042-1060.

Zhu, S.C. (2005) "Can Product Cycles Explain Skill Upgrading?” Journal of International Economics 66(1): 131-155. 
Table 1: Plants in Each Category as a \% of the Total

\begin{tabular}{ccccc}
\hline & $\begin{array}{c}\text { Foreign } \\
\text { Licenses }\end{array}$ & $\begin{array}{c}\text { Foreign } \\
\text { Ownership }\end{array}$ & $\begin{array}{c}\text { Importing } \\
\text { Intermediate Inputs }\end{array}$ & Exporting \\
\hline 1990 & 5.0 & 6.8 & 21.9 & 17.5 \\
1991 & 5.5 & 6.8 & 22.6 & 20.1 \\
1992 & 5.4 & 6.1 & 25.2 & 21.0 \\
1993 & 5.7 & 6.1 & 26.2 & 22.2 \\
1994 & 5.3 & 5.9 & 28.4 & 23.1 \\
1995 & 5.7 & 5.5 & 25.7 & 23.5 \\
1996 & 6.2 & 5.2 & 26.7 & 23.6 \\
1997 & 5.6 & 4.9 & 28.0 & 24.9 \\
1998 & 6.2 & 6.2 & 26.4 & 24.7 \\
1999 & 6.0 & 6.0 & 23.2 & 23.3 \\
Average $1990-1999$ & 5.6 & 6.0 & 25.4 & 22.4 \\
& & & & \\
\hline
\end{tabular}


Table 2: Descriptive Statistics

\begin{tabular}{lccc}
\hline Variable & Obs. & Mean & Std. Dev. \\
\hline & & & \\
Share of skilled labor in wage bill & 31,958 & 0.384 & 0.217 \\
$\ln ($ Capital t-1 / Value Added t) & 31,958 & -0.567 & 1.154 \\
$\ln ($ Value Added t) & 31,958 & 11.078 & 1.663 \\
Foreign Ownership Dummy & 31,958 & 0.059 & 0.236 \\
Foreign Licenses Dummy & 31,958 & 0.063 & 0.243 \\
Export Dummy & 31,958 & 0.248 & 0.432 \\
Importer Intermediate Inputs Dummy & 31,958 & 0.290 & 0.454 \\
\hline
\end{tabular}


Table 3: Share of Skilled Wages in Total Wage Bill - Basic Regressions

\begin{tabular}{|l|c|c|c|c|c|c|}
\hline & $(1)$ & $(2)$ & $(3)$ & $(4)$ & $(5)$ & $(6)$ \\
\hline & All & Non-Exp & Export & All & Non-Exp & Export \\
\hline $\ln ($ Capital / Value Added) & -0.002 & -0.002 & -0.001 & -0.002 & -0.002 & -0.001 \\
\hline & $(1.41)$ & $(1.25)$ & $(0.18)$ & $(1.29)$ & $(1.25)$ & $(0.20)$ \\
\hline $\ln ($ Value Added) & -0.005 & -0.005 & -0.006 & -0.005 & -0.005 & -0.006 \\
\hline Foreign Ownership & $(2.60)^{* *}$ & $(2.27)^{*}$ & $(1.36)$ & $(2.42)^{*}$ & $(2.36)^{*}$ & $(1.33)$ \\
\hline & 0.007 & -0.027 & 0.025 & 0.008 & -0.027 & 0.025 \\
\hline Foreign Licenses & $(0.98)$ & $(2.21)^{*}$ & $(2.93)^{* *}$ & $(1.07)$ & $(2.20)^{*}$ & $(2.94)^{* *}$ \\
\hline & 0.008 & 0.001 & 0.013 & & & \\
\hline Importer Intermediate Inputs & $(2.08)^{*}$ & $(0.17)$ & $(1.98)^{*}$ & & & \\
\hline & 0.006 & 0.003 & 0.003 & & & \\
\hline $\ln$ (RER) & $(2.08)^{*}$ & $(0.91)$ & $(0.56)$ & & & \\
\hline & 0.025 & 0.017 & 0.072 & 0.026 & 0.017 & 0.071 \\
\hline Foreign Licenses / Sales & $(2.31)^{*}$ & $(1.27)$ & $(4.49)^{* *}$ & $(2.37)^{*}$ & $(1.27)$ & $(4.44)^{* *}$ \\
\hline & & & & 0.263 & 0.106 & 0.616 \\
\hline Imported Inputs / Total Inputs & & & & $(2.09)^{*}$ & $(0.65)$ & $(3.17)^{* *}$ \\
\hline & & & & 0.018 & 0.014 & 0.012 \\
\hline Constant & & & $(3.98)^{* *}$ & $(2.17)^{*}$ & $(1.56)$ \\
\hline & 0.353 & 0.310 & 0.243 & 0.349 & 0.310 & 0.247 \\
\hline Observations & $(6.84)^{* *}$ & $(5.20)^{* *}$ & $(2.53)^{*}$ & $(6.82)^{* *}$ & $(5.19)^{* *}$ & $(2.59)^{*}$ \\
\hline R-squared & 31958 & 24024 & 7934 & 31958 & 24024 & 7934 \\
\hline
\end{tabular}

Robust $\mathrm{t}$ statistics in parentheses

+ significant at 10\%; * significant at 5\%; ** significant at $1 \%$. Standard errors clustered at the 3digit ISIC sector and year. 
Table 4: Share of Skilled Wages in Total Wage Bill - Regressions with Changes in RER

\begin{tabular}{|l|c|c|c|c|c|c|}
\hline & $(1)$ & $(2)$ & $(3)$ & $(4)$ & $(5)$ & $(6)$ \\
\hline & All & Non-Exp & Export & All & Non-Exp & Export \\
\hline $\ln ($ Capital / Value Added) & -0.002 & -0.002 & -0.001 & -0.002 & -0.002 & -0.001 \\
\hline & $(1.43)$ & $(1.27)$ & $(0.19)$ & $(1.31)$ & $(1.27)$ & $(0.22)$ \\
\hline $\ln ($ Value Added) & -0.005 & -0.005 & -0.006 & -0.005 & -0.005 & -0.006 \\
\hline & $(2.61)^{* *}$ & $(2.29)^{*}$ & $(1.36)$ & $(2.43)^{*}$ & $(2.37)^{*}$ & $(1.33)$ \\
\hline Foreign Ownership & 0.007 & -0.027 & 0.025 & 0.008 & -0.027 & 0.025 \\
\hline & $(0.97)$ & $(2.20)^{*}$ & $(2.91)^{* *}$ & $(1.07)$ & $(2.20)^{*}$ & $(2.92)^{* *}$ \\
\hline Foreign Licenses & 0.008 & 0.001 & 0.013 & & & \\
\hline & $(2.06)^{*}$ & $(0.15)$ & $(1.97)^{*}$ & & & \\
\hline Importer Intermediate Inputs & 0.006 & 0.003 & 0.003 & & & \\
\hline & $(2.09)^{*}$ & $(0.92)$ & $(0.56)$ & & & \\
\hline $\ln$ (RER) & 0.028 & 0.020 & 0.077 & 0.029 & 0.020 & 0.076 \\
\hline & $(2.40)^{*}$ & $(1.42)$ & $(4.03)^{* *}$ & $(2.47)^{*}$ & $(1.43)$ & $(3.98)^{* *}$ \\
\hline$\Delta \ln ($ RER) & -0.012 & -0.013 & -0.018 & -0.012 & -0.013 & -0.018 \\
\hline & $(0.92)$ & $(0.83)$ & $(0.64)$ & $(0.96)$ & $(0.84)$ & $(0.66)$ \\
\hline Foreign Licenses / Sales & & & & 0.261 & 0.104 & 0.615 \\
\hline & & & & $(2.08)^{*}$ & $(0.63)$ & $(3.16)^{* *}$ \\
\hline Imported Inputs / Total Inputs & & & & 0.018 & 0.014 & 0.012 \\
\hline & & & & $(3.99)^{* *}$ & $(2.17)^{*}$ & $(1.56)$ \\
\hline Constant & 0.341 & 0.300 & 0.222 & 0.337 & 0.296 & 0.226 \\
\hline & $(6.20)^{* *}$ & $(4.69)^{* *}$ & $(2.05)^{*}$ & $(6.19)^{* *}$ & $(4.68)^{* *}$ & $(2.10)^{*}$ \\
\hline Observations & 31,958 & 24,024 & 7,934 & 31,958 & 24,024 & 7,934 \\
\hline R-squared & 0.030 & 0.028 & 0.033 & 0.030 & 0.029 & 0.033 \\
\hline
\end{tabular}

Robust $t$ statistics in parentheses

+ significant at $10 \% ; *$ significant at 5\%; ** significant at $1 \%$. Standard errors clustered at the 3digit ISIC sector and year. 
Table 5: The RER and Export Activity

\begin{tabular}{|l|c|c|c|c|}
\hline & $(1)$ & $(2)$ & $(3)$ & $(4)$ \\
\hline $\ln ($ TFP) & $\begin{array}{c}\text { Export } \\
\text { Dummy }\end{array}$ & $\begin{array}{c}\text { Exports/Sales } \\
\text { (Exporters } \\
\text { Only) }\end{array}$ & $\begin{array}{c}\text { Export } \\
\text { Dummy }\end{array}$ & $\begin{array}{c}\text { Exports/Sales } \\
\text { (Exporters } \\
\text { Only) }\end{array}$ \\
\hline $\ln$ (Labor) & 0.003 & 0.005 & 0.003 & 0.006 \\
\hline & $(1.04)$ & $(1.82)^{+}$ & $(0.97)$ & $(2.42)^{*}$ \\
\hline Foreign Ownership & 0.051 & 0.025 & 0.035 & 0.016 \\
\hline & $(7.25)^{* *}$ & $(5.20)^{* *}$ & $(5.81)^{* *}$ & $(3.35)^{* *}$ \\
\hline Foreign Licenses & 0.055 & 0.005 & 0.042 & 0.003 \\
\hline & $(3.83)^{* *}$ & $(0.49)$ & $(3.14)^{* *}$ & $(0.35)$ \\
\hline Importer Intermediate Inputs & 0.015 & 0.001 & 0.012 & 0.001 \\
\hline & $(1.96)^{+}$ & $(0.32)$ & $(1.54)$ & $(0.27)$ \\
\hline $\ln$ (Age) & 0.029 & -0.003 & 0.014 & -0.005 \\
\hline & $(5.15)^{* *}$ & $(0.75)$ & $(2.56)^{*}$ & $(1.22)$ \\
\hline $\ln$ (RER) & 0.009 & -0.005 & 0.006 & -0.009 \\
\hline & $(1.43)$ & $(0.54)$ & $(0.92)$ & $(0.99)$ \\
\hline Export Dummy & 0.064 & 0.053 & 0.048 & 0.037 \\
\hline & $(3.59)^{* *}$ & $(2.59)^{*}$ & $(3.08)^{* *}$ & $(2.10)^{*}$ \\
\hline Exports/Sales & & & 0.242 & \\
\hline & & & $(16.46)^{* *}$ & \\
\hline Constant & & & & 0.222 \\
\hline & & & -0.212 & $(8.70)^{* *}$ \\
\hline Observations & -0.299 & -0.154 & $(2.82)^{* *}$ & $(0.98)$ \\
\hline R-squared & $(3.57)^{* *}$ & $(1.52)$ & 0.070 & 0.070 \\
\hline & 32,113 & 7,955 & & \\
\hline & 0.010 & 0.012 & & \\
\hline
\end{tabular}

Robust $t$ statistics in parentheses

+ significant at 10\%; * significant at 5\%;** significant at $1 \%$. Standard errors clustered at the 3digit ISIC sector and year. 


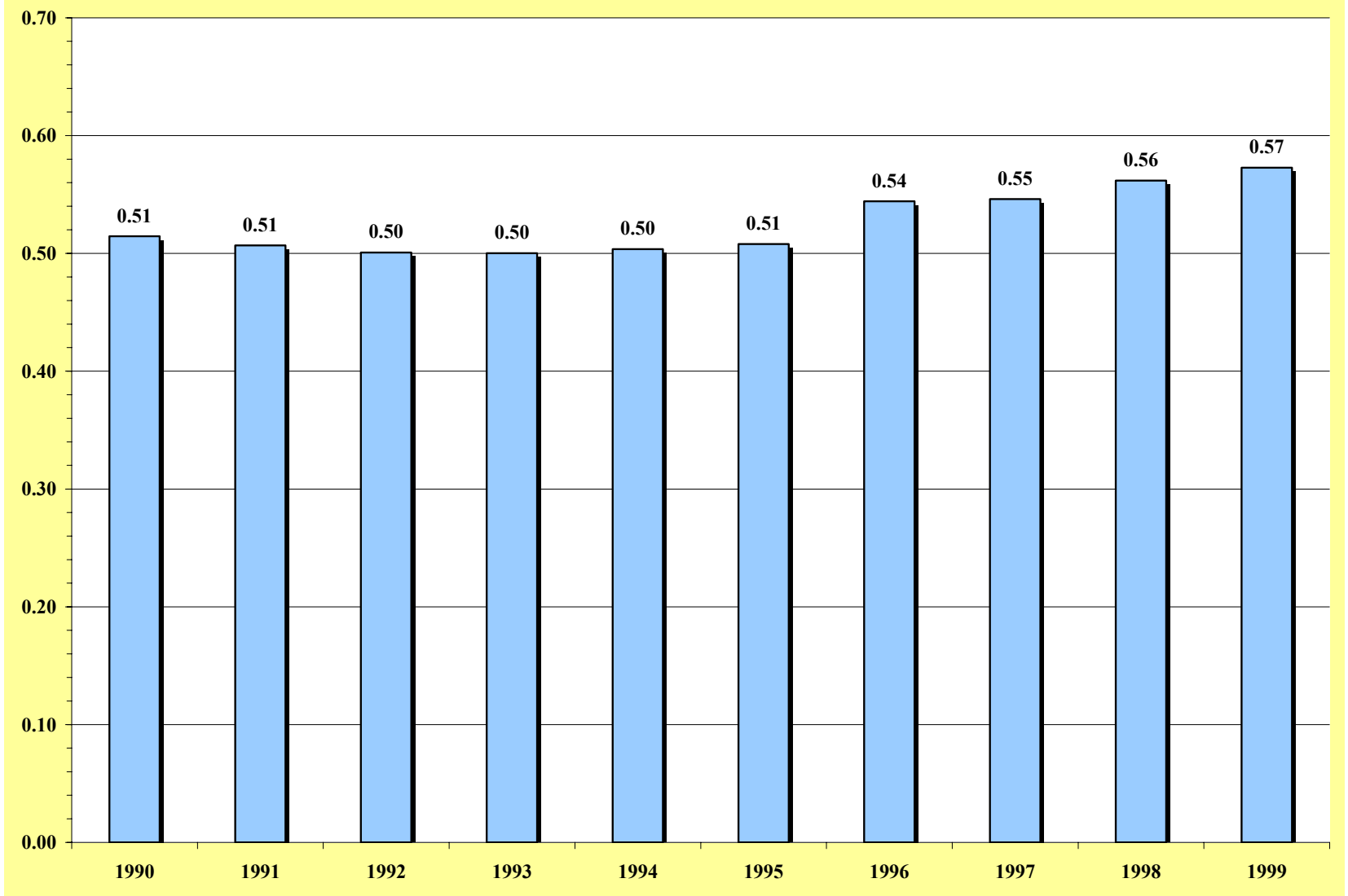

Figure 1: Share of Skilled Labor in Total Wage Bill: All Manufacturing 


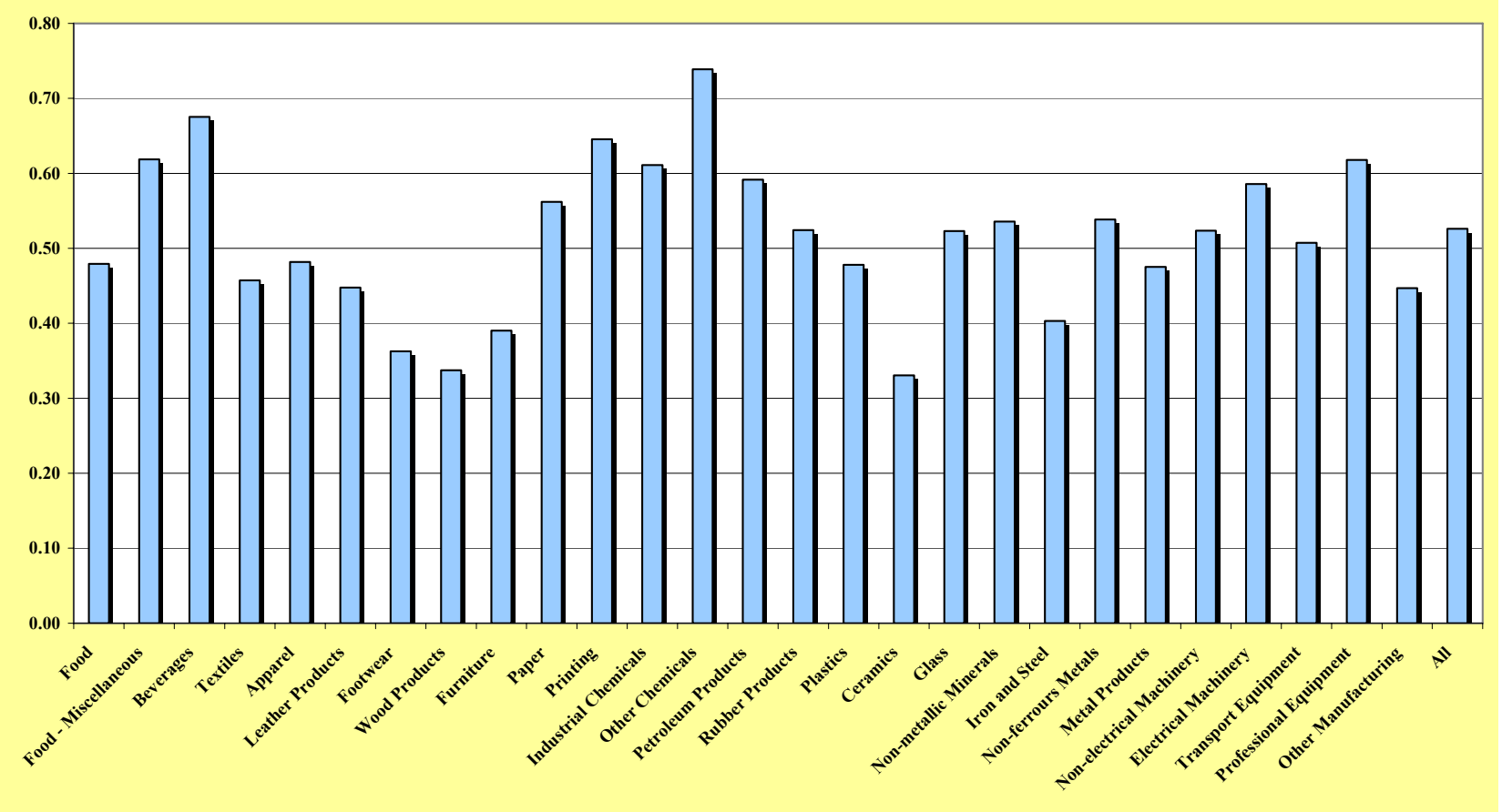

Figure 2: Share of Skilled Labor in Total Wage Bill by 3-digit Sector, Average 1990-99 


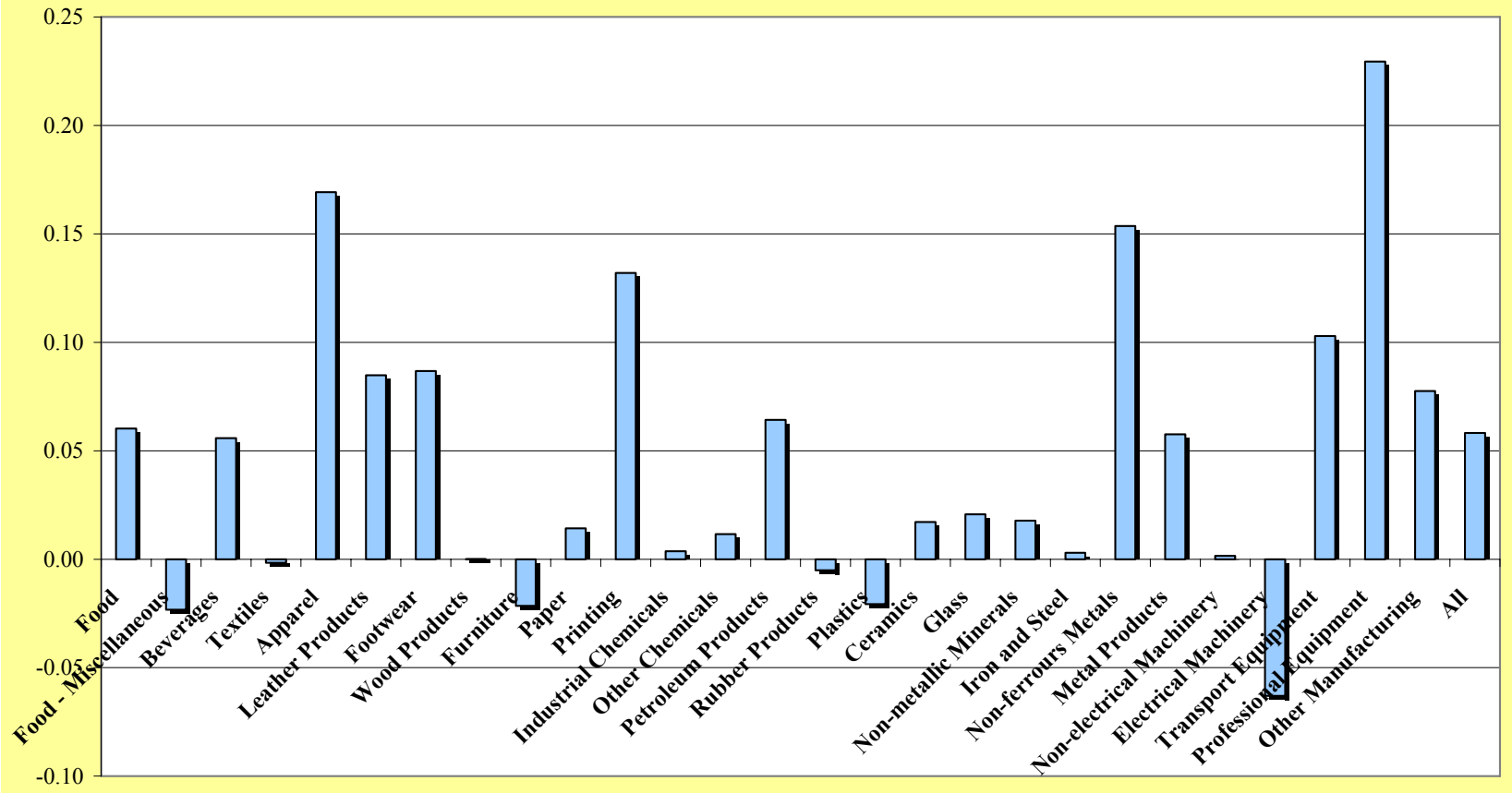

Figure 3: Share of Skilled Labor in Total Wage Bill by 3-digit Sector, Absolute Change 1990-99 


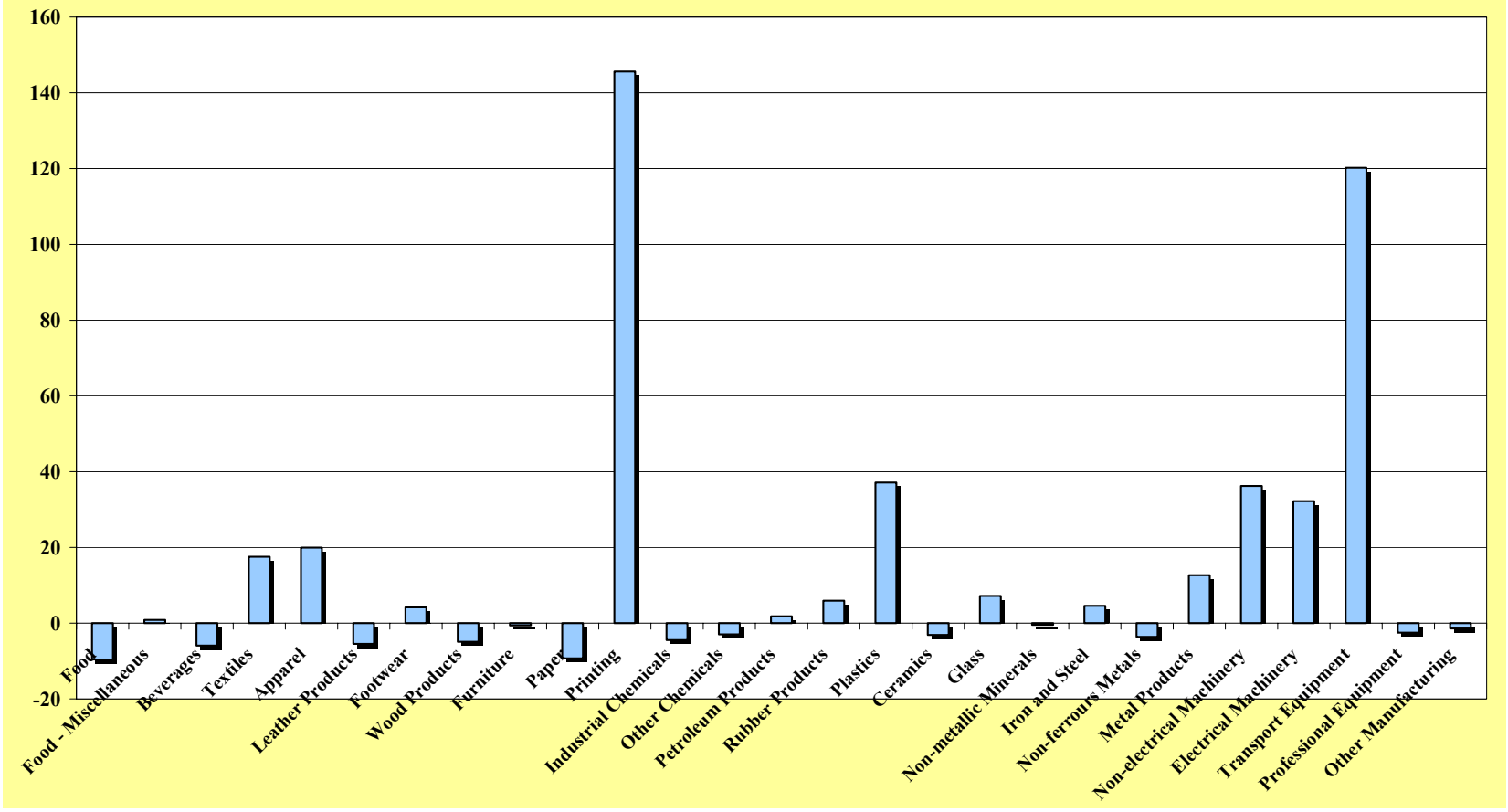

Figure 4: Real Exchange Rate by 3-digit Sector, \% Change 1990-99 